\title{
REvIEW | It's Been Beautiful: Soul! and Black Power Television
}

Gayle Wald

Durham, N.C.: Duke University Press, 2015

ISBN 978-0-8223-5837-4

\author{
Rob Bowman \\ York University \\ rbowman@yorku.ca
}

Soul! was a visionary public education television show aimed squarely at an African American audience, aired between 1968 and 1973, initially on WNET in NYC and, from its second season forward, nationally via PBS distribution. In 2015, very few of this journal's readers, let alone the general public, are likely aware that the show existed. Yet, at the time, Soul! had substantial currency with African Americans and a significant number of Latinos seemingly spanning class, age and gender in the process.

Created and hosted by theatre veteran Ellis Haizlip, Soul! successfully challenged ideas of what constituted the black community, what that community might find meaningful in terms of politics and performance, and how such meaning(s) might be framed. With It's Been Beautiful (a phrase movingly used by Haizlip in conversation with Stokely Carmichael while referring to the impending end of the show's run) Gayle Wald, professor of English and American Studies at George Washington University, tells the story of Soul! in broad strokes while analyzing in detail a handful of specific shows that she feels, in one way or another, capture the diverse content, goals, spirit and affect that the series as a whole conveyed.

Initially modelled on the Tonight Show with Johnny Carson, for Soul! Haizlip programmed a wide variety of black artists and thinkers who were either little known or totally unknown by a mainstream audience. These ranged from musicians such as LaBelle as they transitioned from 1960s girl group to glam rock feminists, the militant proto-rappers The Last Poets and Gil Scott-Heron, and 
Latino band leaders such as Willie Colon and Tito Puente, to poets and writers such as Toni Morrison, Nikki Giovanni and James Baldwin, to political/social thinkers, including the above-mentioned Stokely Carmichael, Amiri Baraka, Louis Farrakhan and Malcolm X's widow Betty Shabazz. In the process, Haizlip (who was openly gay) challenged his guests, his studio audience and his viewers to reflect upon gender, sexuality, the black church, the relationship of blacks and Latinos, Black Power and other issues relevant to the Black community.

Wald's research for It's Been Beautiful is based on twenty-four interviews with people who worked for or appeared on the show, diligently combing through materials in the Ford Foundation, Ellis Haizlip, Public Broadcasting and WNET Archives; viewing of a number of episodes of the show; contemporary articles on Soul! in popular magazines, such as TV Guide and Newsweek; and theoretical writings by cultural theorists ranging from Houston Baker and Audre Lorde to Henry Louis Gates and Mark Anthony Neal.

The overriding thesis of It's Been Beautiful is "to use Soul! as an opportunity 'to go beyond accounts of representation' and focus instead on cultural performance in the televisual construction and negotiation of blackness" (8). Wald uses the term "affective compact" to describe the relationship of trust and affiliation that Haizlip fostered between Soul! and its audience. She divides her book into five chapters plus a lengthy introduction and a short concluding section. Chapter 1 discusses how the foment of the 1960s, including the rise of black nationalism and race rebellions in places such as Watts, Newark and Detroit, created the conditions for a program such as Soul! to be funded. Chapter 2 explores the "affective compact" between the show and its audience while Chapter 3 engages in a close reading of three episodes that are entirely devoted to music, exploring how in each case the political and social meaning of the various performances was at least as important, if not more so, than their value as art and entertainment.

In Chapter 4, entitled "Freaks Like Us: Black Misfit Performance on Soul!", Wald explores the role of women, gays and Black Power representatives on the show, arguing strongly that Haizlip created a program and consequent world that was inclusive, diverse and, perhaps for many in his audience, challenging in the most positive sense.

Chapter 5 interrogates what Wald terms the "racial state" and the cessation of the funding of Soul! as part of a larger agenda during the Nixon years when the federal government did everything it could to undermine any type of television programming that might challenge policies and behavior of the administration.

It's Been Beautiful is ultimately an even-handed discussion that arguably hits on most of the important sociological issues that Soul! articulated and embodied during its five seasons. I would have liked to have seen a more thorough discussion of a greater amount of the series' programming. The details the reader gets in these various chapters, based on a handful of episodes, are tantalizing but I cannot help but feel that the show is in need of a much more detailed historical account.

That said, as is the case with Wald (2007), It's Been Beautiful successfully brings attention, with both dignity and respect, to a neglected but influential and deserving part of African American cultural history. Hopefully this attention might spark further study of Soul! and perhaps lead to greater availability via YouTube, DVD/Blu-ray or a website of a complete run of the show's five seasons. 


\section{References}

Wald, G. 2007. Shout, Sister, Shout!: The Untold Story of Rock-and-Roll Trailblazer Sister Rosetta Tharp. Boston, MA: Beacon Press. 